promptly as at first expected, it would have been sadly out of date by this time. So large an addition has been made to our knowledge of fossil plants, that now we are to have three volumes of this work, instead of two, and the third volume, promised to appear "with as little delay as possible," is to contain the seed plants, and also a much-needed discussion of the geographical distribution of plants at different stages in the history of the earth.

The present volume contains the pteridophytes, with the exception of Equisetales and the major part of Sphenophyllales, which were treated in the first volume. As has been said often in this journal, the material of paleobotany must be traversed critically by morphologically trained paleobotanists, so that morphologists may be able to base their conclusions upon reasonably assured data. Even yet, most paleobotanists are stratigraphers, their chief concern being to be able to recognize a given horizon by a given form, whatever its relationships may be. Of course, such paleobotanists are geologists rather than botanists.

SEWARD has now done this service for botanists in the very critical series of fossil pteridophytes, and we are able to put together two or three competent and independent judgments, feeling well assured if we find agreement, and feeling cautious if we find disagreement. It is impossible to discuss the details of such a book, for it is more a manual than a reading text. It will be sufficient to indicate the titles of the 16 chapters.

XII, Sphenophyllales (continued) (I6 pp.); XIII, Psilotales ( 13 pp.); XIV, Lycopodiales (62 pp.); XV, Arborescent Lycopodiales (I04 pp.); XVI, Sigillaria (3I pp.); XVII, Stigmaria (2I pp.); XVIII, Bothrodendreae (23 pp.); XIX, Seed-bearing plants closely allied to members of the Lycopodiales (9 pp.); XX, Filicales (44 pp.); XXI, Fossil ferns (7I pp.); XXII, Marattiales (fossil) (I 7 pp.); XXIII, Psaronieae ( 5 pp.); XXIV, Ophioglossales (fossil) (5 pp.); XXV, Coenopterideae (9I pp.); XXVI, Hydropterideae and Sagenopteris (II pp.); XXVII, Genera of Pteridosperms, ferns, and plantae incertae sedis (97 pp.).

These titles do not indicate any coordination, but perhaps they represent the legitimate state of mind in the presence of the material.-J. M. C.

\title{
MINOR NOTICES
}

New Zealand plants. - New Zealand is fortunate in having as its leading botanist one who has not only carefully studied the problems of plant life in a comparatively new region, but has now given to the general public a most interesting volume $e^{8}$ on the vegetation of these islands. Beginning with a simple synopsis of the history of botanical explorations in New Zealand, from the work of Dr. John Forster in 1773 to the present day, Dr. CocKayne proceeds to discuss the most notable features of a vegetation ranging from a

${ }^{8}$ Cockayne, L., New Zealand plants and their story. 8vo. vii+rgo. figs. $7 T$. I910. Wellington: John Mackay, Government Printer. 
rain forest of almost tropical luxuriance to xerophytic sand dunes. The ecological viewpoint is maintained throughout, although the fact that the author is writing for a general audience seems to have led him from his usual scientific accuracy to many teleological interpretations. Still, the story of the New Zealand plants is told in so clear and interesting a manner that many botanists of other lands will find the little volume useful in imparting a picture of the vegetation of that distant country. For local use it cannot but be of the greatest service to teachers who are seeking an intelligent appreciation of their surroundings. The needs of the teaching profession are further recognized by a chapter on the cultivation of indigenous plants on the school grounds and in the school garden. The botanist will be interested, among other things, in the considerable number of plants with juvenile and adult leaf forms. The value of the volume is much increased by 70 illustrations from photographs of some of the most remarkable plants described.-GEo. D. FULler.

North American Flora. ${ }^{2}-$ Volume XXV, part 3 , continues the treatment of the Geraniales and includes an elaboration of the Rutaceae and Surianaceae by Percy Wilson, the Simaroubaceae by John Kunkel Small, and the Burseraceae by Joseph Nelson Rose. New species, chiefly from Cuba and Mexico, are described in the following genera: Ravenia (I), Zanthoxylum (3), Spathelia (I), Amyris (I), Elaphrium (7), and Icica (10). One new genus (Castelaria) of the Simaroubaceae is proposed, based on Castela Nicholsoni Hook., to which are referred 8 species, 2 from Cuba being new to science.-J. M. GreenMaN.

Symbolae Antillanae. ${ }^{\mathrm{x}}$ - The publication of a third fascicle completes the sixth volume of Professor Urban's well-known work, Symbolae Antillanae. The fascicle recently issued continues the treatment of the Orchidaceae by A. Cogntaux. There are recognized 96 genera, to which are referred 505 species, 28 being new to science. The excellent keys, careful and full descriptions, copious citation of exsiccatae, and complete synonomy with bibliography, make this a thoroughly scientific and standard work on the Orchidaceae of the Antillean region.-J. M. GreEnMan.

Handbook of deciduous trees.-The tenth part (fifth section of second volume) of SCHNEIDER's Handbuch has just appeared, ${ }^{\text {II }}$ the preceding part

9 North American Flora, Vol. XXV, part 3, pp. 173-26r. New York Botanical Garden. May 6, rgrr.

to Urban, I., Symbolae Antillanae seu fundamenta florae Indiae Occidentalis. Vol. VI, fasc., 3., pp. 433-721. Leipzig: Fratres Borntraeger. I9I0.

II SchneIder, C. K., Illustriertes Handbuch der Laubholzkunde. Zehnte Lieferung (fünfte Lieferung des zweiten Bandes). Imp. 8vo. pp. 497-757. figs. 329-4I9. Jena: Gustav Fischer. I9ri. $M 5$. 


\section{$2 \mathrm{BHL}$ Biodiversity Heritage Library}

1911. "New Zealand Plants." Botanical gazette 52(2), 159-160. https://doi.org/10.1086/330594.

View This Item Online: https://www.biodiversitylibrary.org/item/109458

DOI: https://doi.org/10.1086/330594

Permalink: https://www.biodiversitylibrary.org/partpdf/223449

\section{Holding Institution}

Missouri Botanical Garden, Peter H. Raven Library

\section{Sponsored by}

Missouri Botanical Garden

\section{Copyright \& Reuse}

Copyright Status: Public domain. The BHL considers that this work is no longer under copyright protection.

This document was created from content at the Biodiversity Heritage Library, the world's largest open access digital library for biodiversity literature and archives. Visit BHL at https://www.biodiversitylibrary.org. 